\title{
Teaching Reform of Software Process and Project Management
}

\author{
Yan Changshun, Shao Yong* \\ Faculty of Information Technology, Beijing University of Technology, Beijing, China \\ Email address: \\ yuewuxing@bjut.edu.cn (Yan Changshun), shaoyong@bjut.edu.cn (Shao Yong) \\ ${ }^{*}$ Corresponding author
}

To cite this article:

Yan Changshun, Shao Yong. Teaching Reform of Software Process and Project Management. Higher Education Research. Vol. 6, No. 4, 2021, pp. x-x. doi: 10.11648/j.her.20210605.13

Received: August 23, 2021; Accepted: September 13, 2021; Published: September 14, 2021

\begin{abstract}
Engineering education professional certification is an internationally accepted engineering education quality assurance system and an important basis for realizing international mutual recognition of engineering education and engineer qualification. The purpose is to ensure that engineering graduates have the comprehensive ability to adapt to social engineering work. The evaluation is oriented by training objectives and graduation requirements. There are seven aspects of engineering education professional certification, of which the most core is students. The ultimate goal is to meet the graduation requirements, and the specific guarantee is the training goal. Passing the engineering education certification has become an important work of undergraduate education and training. Based on engineering certification and under the guidance of the goal of software engineering major of Software College of Beijing University of technology, this paper compares the syllabus of software process and project management in 2015 and 2020. This paper makes a detailed comparative analysis from the aspects of teaching objectives, teaching contents, teaching methods and assessment methods. The comparison results show that the revision of the curriculum according to the engineering certification has brought more positive changes. It is hoped that the results of the reform can provide some inspiration to relevant teaching personnel.
\end{abstract}

Keywords: Engineering Education Professional Certification, Teaching Objectives, Teaching Contents, Teaching Methods, Assessment Methods

\section{Introduction}

Nowadays, China's engineering education is growing, and the proportion of engineering majors is increasing year by year, accounting for about one third of the total number of majors [1]. At the same time, regional economic development is diversified [2], and the demand for engineering talents to adapt to the society is gradually expanding [3]. It is very necessary to open and develop the professional certification of engineering education [4]. When the engineering education certification system is fully mature, it can be used as a bridge between industry and engineering education [5], so that engineering talents are not only excellent in basic knowledge [6-9], but also become new talents to adapt to engineering development and social forms [10]. In the future, realizing the equivalence between the essence of Engineering Education in China and the international essence and realizing international mutual recognition is also one of the important reasons for the existence of the professional certification system of engineering education $[11,12]$. The degree of specialization of engineering education is becoming increasingly prominent, and the demand for professional talents is also increasing [13]. In the near future, the guarantee of the professional certification system of engineering education will become an important guarantee system for the cultivation of engineering talents $[14,15]$. The software school of Beijing University of technology has accumulated a lot of successful experience in software engineering education and achieved fruitful results. In recent years, we are also committed to promoting the professional development with the engineering education certification system. Software process and project management is a professional course for undergraduates majoring in software engineering. The task of this course is to teach the basic theories and methods of software process and project management, some successful cases and the new concept of agile project management. The teaching content 
focuses on the introduction of software process and project management concept; Preparation of scope, time, cost and integration plan; Understanding of agile concept; Understanding of Scrum model. The difficulty of teaching content is the understanding of agile concept and the preparation of integration plan. Through the systematic study of this course, students are required to master the traditional management process and agile project management process of software project. Finally, it has the ability to prepare integrated plans; Good communication and teamwork skills;
Ability of software project initiation, execution control, acceptance management, etc. The following is a comparative analysis of this course from the aspects of teaching objectives, teaching contents, teaching methods and assessment methods to illustrate the effectiveness of our reform.

\section{Reform of Teaching Objectives}

The teaching objectives of software process and project management in 2015 and 2020 are shown in Table 1 and table 2.

Table 1. Relationship matrix between 2015 curriculum objectives and graduation requirements.

\begin{tabular}{ll}
\hline Course objectives & Graduation requirement index point \\
\hline Course objective 1: understand the concept of & 2.2 correctly express the complex engineering problems related to software engineering by establishing \\
software project management, understand the & mathematical model, system integration, performance analysis and other methods. \\
knowledge system of software project & 9.1 good communication and teamwork skills. \\
management, master contract management, and & 11.1 master the management and economic decision-making methods involved in the project; \\
master the preparation of plans such as scope & 11.2 understand the cost composition of the whole cycle and process of engineering and products, and \\
and progress. & understand the engineering management and economic decision-making involved. \\
Course objective 2: understand the concept of & 2.2 correctly express the complex engineering problems related to software engineering by establishing \\
software process, software quality model and & mathematical model, system integration, performance analysis and other methods. \\
CMMI. Master the software process & 9.1 good communication and teamwork skills. \\
specification and model, and master the & 11.1 master the management and economic decision-making methods involved in the project; \\
improvement methods of software process. & 11.2 understand the cost composition of the whole cycle and process of engineering and products, and \\
\end{tabular}

Table 2. Relationship matrix between 2020 curriculum objectives and graduation requirements.

\begin{tabular}{|c|c|}
\hline Course objectives & Graduation requirement index point \\
\hline $\begin{array}{l}\text { Course objective 1: master the legal knowledge in contract management and project } \\
\text { acceptance, establish the concept of rule of law, and abide by discipline and law. }\end{array}$ & $\begin{array}{l}\text { 1: Establish socialist core values and correct world outlook and } \\
\text { outlook on life, be patriotic and dedicated, and have good moral } \\
\text { cultivation and sense of social responsibility; Pay attention to } \\
\text { humanistic quality, establish the concept of rule of law and civic } \\
\text { awareness, abide by discipline and law, and academic ethics; Master } \\
\text { certain labor skills, advocate labor and develop good habits of labor. }\end{array}$ \\
\hline $\begin{array}{l}\text { Course objective } 2 \text { : master the knowledge of communication and teamwork, and have } \\
\text { good communication and teamwork skills: students need to communicate, coordinate } \\
\text { and cooperate with each other in team formation, division of labor, system design, } \\
\text { written reports and other links. }\end{array}$ & 10.1: good communication and teamwork skills. \\
\hline $\begin{array}{l}\text { Course objective } 3 \text { : master the knowledge of management and economic } \\
\text { decision-making methods involved in software projects, and have the ability to use } \\
\text { these methods for software project initiation, planning, execution control, acceptance } \\
\text { management, etc. }\end{array}$ & $\begin{array}{l}\text { 12.1: master the management and economic decision-making } \\
\text { methods involved in the project; }\end{array}$ \\
\hline
\end{tabular}

Table 3. Teaching content of 2015 Edition.

\begin{tabular}{lll}
\hline chapter & primary coverage & total \\
\hline 1 & Overview of software project management & 4 \\
2 & Software project management initial & 4 \\
3 & Software project management plan & 6 \\
4 & End of software project management & 2 \\
5 & Fundamentals of software process & 2 \\
6 & Software process model & 4 \\
7 & Software process improvement & 3 \\
8 & software quality & 4 \\
9 & CMMI & 3 \\
total & & 32 \\
\hline
\end{tabular}

By comparing the curriculum objectives of 2015 and 2020, we will find several changes:

(1) The number of graduation requirements for support is less. In the past, a course emphasized more support points, but now it emphasizes really meaningful strong support.

(2) In addition to the technical indicators required for graduation, there are more ideological and political indicators. It is emphasized that we should have both morality and talent.

(3) Goals and graduation requirements have changed from many to many to one. This is more suitable for the subsequent reasonable evaluation of graduation requirements.

(4) The description of curriculum objectives is more specific and reasonable.

\section{Teaching Content Reform}

The teaching content of the course is the basis for the realization of teaching objectives. The teaching contents of 2015 and 2020 versions of software process and project 
management are shown in Table 3 and table 4.

Table 4. Teaching content of 2020 Edition.

\begin{tabular}{llcc}
\hline primary coverage & total & Course objectives ( $\sqrt{\text { ) }}$ & \multicolumn{2}{c}{$\mathbf{2}$} \\
\cline { 2 - 3 } & & $\mathbf{3}$ & $\sqrt{ }$ \\
Overview of software project management & 2 & $\sqrt{ }$ \\
Software project management initial & 2 & $\sqrt{ }$ \\
Software project management plan & 8 & $\sqrt{ }$ \\
Software process and project management execution and control & 2 & $\sqrt{ }$ \\
End of software project management & 2 & $\sqrt{ }$ \\
Deep understanding of agile concepts & 2 & $\sqrt{ }$ \\
Scrum agile software development process & 2 & $\sqrt{ }$ \\
Agile project management experiment & 12 & $\sqrt{ }$ \\
\end{tabular}

By comparing the teaching contents of 2015 and 2020, we will find several changes:

(1) The scope of teaching content is relatively small. The 2015 training program is a combination of the two courses in 2012, software project management and software process management. Therefore, the content of the original two courses is divided into 16 class hours, but the teaching content is the same. In this way, the content is too extensive, but students generally reflect that the content is too much and difficult to digest. The 2020 edition has selected the content to make the curriculum system more refined and students' goals more clear.

(2) The teaching content adds the cutting-edge concepts and methods of agile software project management.

(3) The specific corresponding relationship between teaching content and teaching objectives is established, which makes the pertinence of the content more clear.

(4) The content link of experimental teaching is added, which is more conducive to students' understanding of theory.

\section{Reform in Teaching Methods}

\subsection{Reform of Case Teaching Method}

The teaching method of this course used to be theory centered. Although there are cases in the 2015 version, it lacks refinement of cases, while the case analysis in the 2020 version increases the depth of cases. The following is a teaching case of version 2020:

The PPT shows a "on-the-job recruitment of the Internet Banking Department of the head office of a bank", which gradually achieves the set teaching objectives through classroom interactive discussion of recruitment cases.

(1) Process

a. give students a few minutes to find the valuable information they are interested in through the data in the form;

b. let 2-3 students speak at random to express their views;

c. ask if you have more new ideas to add;

d. summarize students' views and fully affirm good ones;

e. lead everyone to analyze the form and supplement the enlightenment that students do not realize.
(2) Guiding points

a. under the age of 35 , the emphasis of graduate education is that the pressure of professional competition exists objectively. We should have crisis awareness, competition awareness and learning awareness in order to meet the challenges in the future;

b. computer related majors are required for various posts, emphasizing the diversity of students' career choices in the future, not only software technicians (many students have this misunderstanding in choosing a job);

c. the emphasis of "especially excellent people, some of the above conditions can be relaxed appropriately" is to be full of confidence in employment. Through the case of noodle bully, tell these students who are soon facing career choices that many times your success is not better than others, but more confident;

d. A simple form can get a lot of valuable information through deep excavation, so don't talk about big data, and small data also have the essence.

e. the emphasis of the extension is that some students majoring in software engineering actually want to engage in non computer majors such as finance and securities. It is very unlikely to achieve the goal due to lack of professional knowledge after graduation, but they can focus on software companies serving these fields during employment. Through several years of work, you can deeply master the business and processes in this field, Then use your spare time to supplement some professional knowledge, you may achieve the goal you want; This can also provide a reference for students' future career transformation.

\subsection{Reform of Teaching Method Combining Theory with Practice}

The reform of teaching method combining theory and practice. The teaching of 2015 edition mainly focuses on theoretical professors, and the experimental link is added in 2020 edition to enhance students' practical ability. The content and requirements of the experiment are to complete at least two iterative development of the system through a self selected project and agile development mode under the guidance of teachers. Complete practical activities according 
to agile development principles, practical methods and scrum process. The summary experimental requirements are shown in Table 5. The specific experimental requirements and process are not described here.

Table 5. Agile project management experiment.

\begin{tabular}{lllll}
\hline Serial number & Name of experimental project & nature & Class hours \\
\hline Experiment 1 & First iteration development based on Scrum & Comprehensive & 6 & Number / group \\
Experiment 2 & Second iteration development based on Scrum & Comprehensive & 6 & $4-7$ \\
\hline
\end{tabular}

\section{Reform of Assessment Methods}

The assessment method of curriculum is the basis to measure the achievement of curriculum objectives. The assessment of 2015 and 2020 versions of software process and project management are shown in Table 6 and table 7.

Table 6. Proportion of each part of 2015 curriculum comprehensive score.

\begin{tabular}{ll}
\hline Attendance score & 10 \\
Homework achievement & 10 \\
final exam & 80 \\
total & 100 \\
\hline
\end{tabular}

The assessment results of the 2015 version of the course are based on the hundred mark system. The course results are composed of attendance results, homework results and final examination, and the hundred mark system is adopted. The proportion of each part is as follows:

(1) The attendance score accounts for $10 \%$, mainly assessing the enthusiasm of class.

(2) The homework score accounts for $10 \%$, which mainly investigates the students' understanding and mastery of the knowledge.

(3) The final score accounts for $80 \%$. The examination method is adopted, and the examination is in the form of open book. The types of questions are judgment questions, multiple-choice questions, short answer questions, calculation and analysis questions, etc. The assessment content mainly includes the basic concepts, principles, technologies and methods of software process and project management.

Table 7. Assessment method and score evaluation distribution form of 2020 Edition.

\begin{tabular}{lll}
\hline $\begin{array}{l}\text { Assessment } \\
\text { method }\end{array}$ & $\begin{array}{l}\text { Proportion } \\
(\%)\end{array}$ & Main assessment contents and support for split index points of graduation requirements \\
\hline $\begin{array}{l}\text { Attendance } \\
\text { score }\end{array}$ & 5 & $\begin{array}{l}\text { It mainly assesses students' learning attitude and self-discipline ability. } \\
\text { Focus on supporting graduation requirement indicator point } 1\end{array}$ \\
$\begin{array}{l}\text { Experimental } \\
\text { results }\end{array}$ & 45 & $\begin{array}{l}\text { Through an optional project and adopting agile development mode, at least two iterations of the system are completed. } \\
\text { Complete practical activities according to agile development principles, practical methods and scrum process. } \\
\text { Focus on supporting graduation requirements index points 10.1 and 12.1 } \\
\text { Overview of software process and project management, initial software process and project management, software process } \\
\text { and project management plan, implementation and control of software process and project management, end of software } \\
\text { process and project management, in-depth understanding of agile concept, Scrum agile software development process } \\
\text { Key support graduation requirements index point 1, 12.1 }\end{array}$ \\
\hline
\end{tabular}

The main purpose of 2020 curriculum assessment is to assess students' achievement of curriculum objectives. Course scores include attendance scores, experimental scores and examination scores.

Assessment method and score evaluation distribution:

(1) The attendance score is $5 \%$, the experimental score is $45 \%$, and the examination score is $50 \%$.

(2) The attendance score is $5 \%$, which mainly examines the students' learning attitude and self-discipline ability.

(3) The experimental score is $45 \%$, which mainly investigates the students' ability of communication and teamwork and the ability to apply the learned knowledge to solve practical problems (see the experimental syllabus of "software process and project management" for details).

(4) The test score is $50 \%$, which mainly assesses the students' mastery of basic concepts, basic methods and basic theories, as well as the students' ability to use the theoretical knowledge to solve complex problems.

By comparing the course assessment methods of 2015 edition and 2020 edition, several changes will be found:
(1) Assessment forms are more diversified. In the past, the assessment emphasized the written test results, which may lead to high scores and low ability. Now the assessment emphasizes the comprehensive test of theory and practice. More emphasis is placed on the application of learning.

(2) The assessment content defines the index points of graduation requirements, avoiding the problem of patchwork achievement in the past.

(3) The scope of assessment is further clarified, which is more conducive to the professional monitoring of curriculum documents.

\section{Conclusion}

Software process and project management is a professional basic course of software engineering. It is an important supporting course for students' software engineering management ability. By comparing the teaching objectives, teaching contents, teaching methods and assessment methods of the course, the results show that the revision of the course 
according to engineering certification has brought positive changes. In the future, we will continue to further reform the curriculum according to the concept of engineering certification. We also hope that the majority of software project management workers can put forward more constructive reforms to continuously promote the vigorous development of the professional field of software engineering.

\section{Acknowledgements}

My thesis would like to thank the course construction project (040000513125) of School of software, Faculty of information Technology, Beijing University of technology for its financial support. In the process of our research, the required experimental and testing environment is also provided by the college. At the same time, I would also like to thank the authors of references and related researchers. Their research has given me important reference and help, and provided a good reference for the completion of my thesis.

\section{References}

[1] Haitao Yu, You Xie, Wei Liu, Study on Systematic Design and Implementation of Curriculum Ideology and Politics in the Context of Engineering Education Accreditation. Research in Higher Education of Engineering, Vol 3, 2021, pp. 100-103, 151

[2] Zhiyi Li, The "last mile" of professional certification of Engineering Education in China. Higher Education Development and Evaluation, Vol 3, 2020, pp. 1-13.

[3] Fei Wang, Shenghui Liu, Yuxiang Cui, houghts on the construction of new engineering courses in Local Engineering Colleges under the background of engineering education professional certification. Journal of Higher Education, Vol 3, 2021, pp. 63-66.

[4] Yang Liu, Xia Tian, Research on professional practice teaching standard from the perspective of engineering education professional certification. University Education, Vol 3, 2021, pp. 11-15.

[5] Qilin Zhang, Yongbiao Zhao, Dongsheng Xiang, Integration path of curriculum ideological and political education and engineering education professional certification. Computer Education, Vol 3, 2021, pp. 76-80.

[6] Guobin Zeng, Research on professional certification of engineering education and CDIO training mode. Journal of Higher Education, Vol 7, 2021, pp. 77-80.

[7] Jian Zhang, Research on continuous improvement operation mechanism and evaluation system under engineering education professional certification standard. Heilongjiang Education, Vol 57, 2021, pp. 52-53.

[8] Rongcun Guo, Research on promoting the construction of first-class undergraduate specialty in local universities with engineering education certification. Science \& Technology Vision, Vol 9, 2021, pp. 67-69.

[9] Jing Bai, Yangnan Liu, Analysis on the construction of innovative education and teaching system under the background of engineering education professional certification. China Economist, Vol 7, 2021, pp. 143-144.

[10] Chenzhong Bin, Deming Li, Jianhua Huang, Research on the Innovative and Entrepreneurial Student Training Mode under the Engineering Education Certification. The Theory and Pracice of Innovation And Entreptrneurship, Vol 4, 2021, pp. 119-120, 123.

[11] Shujun Ding, Junying Wei, Xiaojun Meng, Research on the teaching of professional comprehensive innovative design course based on engineering education professional certification. University Education, Vol 6, 2021, pp. 65-67.

[12] Chen Gu, Heming Chen, Exploration of Teachers' Responsibility in Engineering Education Accreditation. Research in Higher Education of Engineering, Vol 3, 2020, pp. 104-108.

[13] Wei Chen, The Relationship Between Innovation Ability Training and Engineering Education Specialty Certification. jiaoyu jiaoxue luntan, Vol 9, 2020, pp. 143-144.

[14] Hong Li, Research on the Cultivation of University Students' Innovation and Entrepreneurship Ability under the Background of Engineering Education Accreditation. jiaoyu jiaoxue luntan, Vol 38, 2020, pp. 321-322.

[15] Lei Gui, Huaging He, Wei Wang, Thoughts on the Status of the Engineering Education Professional Certification Work in Mainland China. jiaoyu jiaoxue luntan, Vol 7, 2020, pp. 339-341. 